\title{
Methionine, leucine, isoleucine, or threonine effects on mammary cell signaling and pup growth in lactating mice
}

\author{
G. M. Liu, ${ }^{*}$ M. D. Hanigan,† X. Y. Lin, ${ }^{*}$ K. Zhao, ${ }^{*}$ F. G. Jiang, ${ }^{*}$ R. R. White,† Y. Wang, ${ }^{*} Z$. Y. Hu, ${ }^{*}$ \\ and Z. H. Wang*1 \\ *Ruminant Nutrition and Physiology Laboratory, College of Animal Science and Technology, Shandong Agricultural University, \\ Taian 271018, P. R. China \\ †Department of Dairy Science, Virginia Tech, Blacksburg 24061
}

\begin{abstract}
Two studies were undertaken to assess the effects of individual essential AA supplementation of a proteindeficient diet on lactational performance in mice using litter growth rates as a response variable. The first study was designed to establish a dietary protein response curve, and the second to determine the effects of Leu, Ile, Met, and Thr supplementation of a protein-deficient diet on lactational performance. In both studies, dams were fed test diets from parturition through d 17 of lactation, when the studies ended. Mammary tissue was collected on $\mathrm{d} 17$ from mice on the second experiment and analyzed for mammalian target of rapamycin (mTOR) pathway signaling. Supplementation with Ile, Leu, or Met independently increased litter weight gain by 11,9 , and $10 \%$, respectively, as compared with the protein-deficient diet. These responses were supported by independent phosphorylation responses for mTOR and eIF4E binding protein 1 (4eBP1). Supplementation of Ile, Leu, and Met increased phosphorylation of mTOR by 55,34 , and $47 \%$, respectively, as compared with the protein-deficient diet. Phosphorylation of $4 \mathrm{eBP} 1$ increased in response to Ile and Met supplementation by 60 and $40 \%$, respectively. Supplementation of Ile and Met increased phosphorylation of Akt/protein kinase B (Akt) by 41 and 59\%, respectively. This work demonstrated that milk production responds nonlinearly to protein supply, and milk production and the mTOR pathway responded independently to supplementation of individual AA. The former demonstrates that a linear breakpoint model is an inappropriate description of the responses, and the latter demonstrates that no single factor limits AA for lactation. Incorporation of a multiple-limiting AA concept and nonlinear responses into milk protein response models will help improve
\end{abstract}

Received September 7, 2016.

Accepted January 3, 2017.

${ }^{1}$ Corresponding author: zhwang@sdau.edu.cn milk yield predictions and allow derivation of diets that will increase postabsorptive $\mathrm{N}$ efficiency and reduce $\mathrm{N}$ excretion by lactating animals.

Key words: single amino acid, litter growth rates, cell signaling, mice

\section{INTRODUCTION}

It has been reported that the utilization of $\mathrm{N}$ for milk production by dairy cows was approximately $25 \%$, with the remainder lost in urine and feces (Spears et al., 2003; Nadeau et al., 2007). This N loss is a significant economic loss for dairy producers and a critical source of environmental pollution (Hanigan et al., 1998). Considering the significant correlation between $\mathrm{N}$ intake and $\mathrm{N}$ excretion, in particular urinary $\mathrm{N}$ (Kebreab et al., 2001), it is very likely that dairy cows are fed protein above their true needs due to poor definitions of AA requirements. Dietary AA formulation is based on the single-limiting AA theory laid out by Mitchell and Block (1946) according to von Liebeg (1863). The single-limiting AA concept assumes that transfer of AA from the gut lumen to milk protein occurs at a constant efficiency until requirements are met and at 0 efficiency thereafter (a linear, breakpoint model); thus, the process is substrate limited with no adaptability. However, it has been demonstrated that AA not only serve as substrates for protein synthesis, but also regulate translation initiation and elongation via one or more cell signaling pathways (Shah et al., 2000; Anthony et al., 2002; Appuhamy et al., 2011a, 2012). Such regulation coupled with variable mammary AA transport activity confers variable AA use efficiency, which violates the fixed efficiency assumption that is critical to the framework proposed by Mitchell and Block (1946).

The integrated stress response and mammalian target of rapamycin (mTOR) pathways control translation initiation and elongation rates, and these pathways are affected by specific AA. The former regulates translation initiation through recruitment of the initiator 
Met-transfer RNA to $40 \mathrm{~S}$ ribosomal subunits. This process is mediated by eukaryotic initiation factor 2 (eIF2), which can be phosphorylated at Ser51 resulting in inhibition of its function (Kimball and Jefferson, 2006). It has been demonstrated that AA mediate phosphorylation of eIF $2 \alpha$ through the general control non-repressible kinase (GCN2) in mouse embryonic stem cells (Harding et al., 2000). Total EAA starvation in culture increased eIF $2 \alpha$ phosphorylation in bovine mammary cells (Appuhamy et al., 2011a); however, the absence of individual EAA had only numerical effects on eIF2 $\alpha$ phosphorylation (Appuhamy et al., 2012).

Amino acid availability also regulates the mTOR signaling pathway, which controls rates of translational initiation by repressing the inhibitory activity of eIF4E binding protein 1 (4eBP1), increasing rates of elongation by stimulating eukaryotic elongation factor 2 (eEF2), and possibly by enhancing ribosomal activity through activation of ribosomal protein S6 (Arriola Apelo et al., 2014). Removing Leu from medium had significant inhibitory effects on mTOR signaling (Kimball, 2001). Similarly elevated Leu was found to stimulate mTOR signaling in muscle cells (Escobar et al., 2006; Avruch et al., 2009). In bovine mammary tissue, deprivation of all AA or removing Leu or Ile individually affected phosphorylation of the downstream mTOR protein ribosomal protein S6 kinase 1 (S6K1) and casein fractional synthesis rates (FSR; Appuhamy et al., 2012). Removing Met also decreased phosphorylation of mTOR and casein FSR. Eukaryotic elongation factor 2, also thought to be under the control of mTOR, inhibits elongation when phosphorylated on Thr56 (Redpath et al., 1996). It has been suggested that eEF2 may be a limiting factor in milk protein synthesis (Christophersen et al., 2002). Removing all EAA from the medium increased eEF2 phosphorylation in bovine mammary tissue (Appuhamy et al., 2012), and individual EAA (Leu, Ile, Met, Thr) removal had differing effects on signaling proteins and casein FSR of mammary tissue in vitro (Appuhamy et al., 2012).

These responses are supported by inducible AA transport rates (Bequette et al., 2001), which serve to maintain the supply of each AA as their use is altered. These integrative, multifactorial responses are difficult to reconcile with a linear, breakpoint model, and the concept of a single-limiting AA and strict order of limitation as laid out by Mitchell and Block (1946). Thus, we hypothesized that supplementation of a protein deficient diet with individual EAA would independently improve lactational performance via the effects of EAA on cell signaling responses, and the responses would be inconsistent with the concept of a single-limiting AA theory. The objective of the present study was to investigate the independent effects of supplementation of a protein deficient diet with Leu, Ile, Met, and Thr on lactational performance in vivo.

\section{MATERIALS AND METHODS}

\section{Animals and Experimental Design}

Two studies were undertaken. The first study was designed to assess lactational responses to dietary protein, and the second study was designed to determine the independent effects of Leu, Ile, Met, and Thr supplementation of a protein deficient diet on lactational performance.

All animal work was approved by the Animal Welfare and Health Committee of Shandong Agricultural University. Pregnant mice were purchased from the Shandong University (Jinan, China) Laboratory Animal Center at $15 \mathrm{~d}$ of pregnancy. Mice were housed in a vivarium under controlled conditions. The system was set to maintain conditions between 22 and $24^{\circ} \mathrm{C}$ at 55 to $60 \%$ humidity with $10 \mathrm{~h}$ of light and $14 \mathrm{~h}$ of darkness throughout the study. Whereas this was achieved in the second study, the facility controls did not consistently maintain these conditions in the first study due to poor temperature between 18 and $20^{\circ} \mathrm{C}$.

In both studies, dams were fed the test diets from parturition through the end of the study. Each dam was housed in an individual cage. Feed offered and orts were measured and recorded daily during the second study. At birth, pups were weighed and randomly culled to a total of 8 pups per litter to ensure a consistent litter size for each dam. Litter weight was measured at end of the study and used to calculate weight gain, which was the response variable. Some infanticide and maternal or pup death occurred. Litters experiencing death of the dam $[\mathrm{n}=8$ (1st); 14 (2nd)] were excluded from the analyses. Litters experiencing infanticide $[\mathrm{n}=12$ (1st); 9 (2nd)] were included in results, as infanticide represented nutrient recycling to the dam. In this case, the initial weight of consumed offspring was included in the calculations. The occurrence of this recycling likely introduced some error, as the efficiency of use of the recycled $\mathrm{N}$ would not be equal to dietary $\mathrm{N}$; however, there was no simple way to correct for this effect and the net result would have been under-prediction of net nutrient supply to the dam, which represents a conservative estimate of the responses.

In the first experiment, modified American Institute of Nutrition (AIN)-76a purified diets, containing 6, 9, $12,15,18,21,24$, or $27 \%$ protein, were fed for $17 \mathrm{~d}$ to lactating mice ( $\mathrm{n}=10$ litters/treatment) to establish a dietary protein response curve. All diets were isocaloric (Trophic Animal Feed High-tech Co. Ltd., Nantong, China). Diet composition is described in Table 1. 
Table 1. Composition (\% as fed) of experiment 1 diets

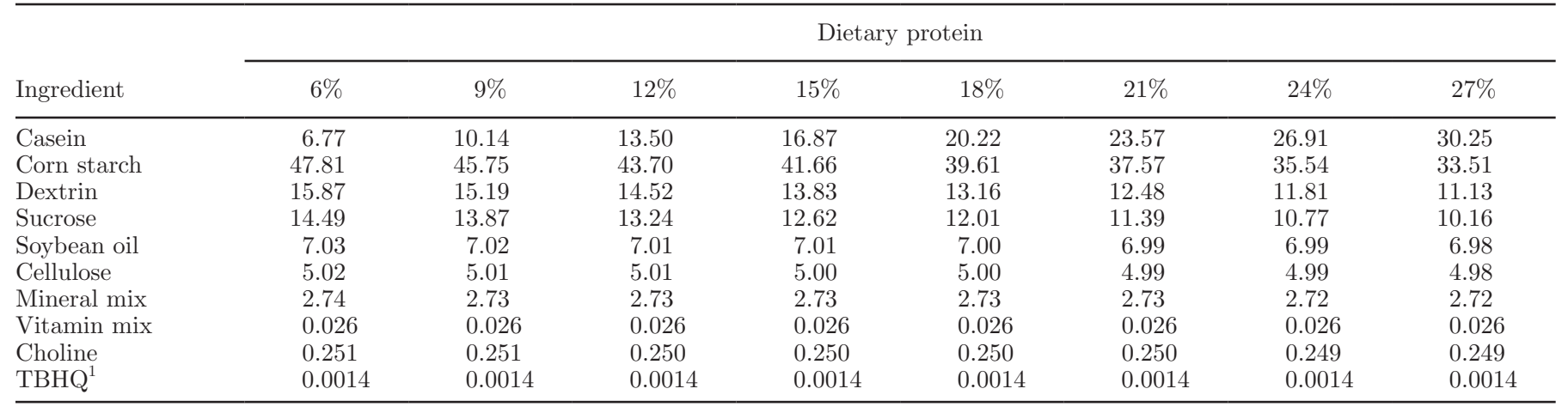

${ }^{1}$ Tert-butyl hydroquinone.

Based on the observed half-maximal response and infanticide rates, the $15 \%$ protein diet was selected for use in the second experiment as the base (protein-deficient) diet, and the $21 \%$ protein diet as a positive control. The second experiment examined the effects of independent additions of Leu, Ile, Met, and Thr to the $15 \%$ protein diet, and the amounts of addition AA were equal to the intake of that AA from the $21 \%$ protein diet (Table 2), yielding a total of 6 treatments. All diets were isocaloric based on ME factors of $4 \mathrm{kcal} / \mathrm{g}$ of carbohydrate and protein and $9 \mathrm{kcal} / \mathrm{g}$ of fat (Merrill and Watt, 1973). Diets (Trophic Animal Feed High-tech Co. Ltd.) were fed once a day for $17 \mathrm{~d}$. Twenty litters were assigned to each treatment.

\section{Sample Collection and Measurement}

On d 17 postbirth, dams were killed by decapitation and offspring were weighed. Blood samples were col- lected via ocular sampling, and mammary tissue was excised and transferred within 3 min to liquid nitrogen.

The glands from the right side of the body were used for Western blotting and the left side for detecting ATPase activity and gene expression. Frozen mammary tissue samples $(100 \mathrm{mg})$ from each of 8 mice per treatment group were subsequently homogenized in $196 \mu \mathrm{L}$ of RIPA lysis buffer (1\% NP-40, $0.5 \%$ sodium deoxycholate, 0.1\% SDS; FD0008, Fdbio Science, Hangzhou, China) containing $2 \mu \mathrm{L}$ of a protease inhibitor containing pepstatin, leupeptin, and aprotinin (FD1265, Fdbio Science) and $2 \mu \mathrm{L}$ of a phosphatase inhibitor mixture (Thr, Ser, Tyr, alkaline, and acid phosphatase inhibitors, FD1260, Fdbio Science). The lysates were assessed for total protein concentrations using a BCA protein assay (Fudebio-tech, FD2001, Hangzhou, China). A volume of the lysate was combined with sample loading and lysis buffer, boiled in a dry bath at $100^{\circ} \mathrm{C}$ for 10 min, and stored at $-20^{\circ} \mathrm{C}$. Forty micrograms of protein

Table 2. Composition ( $\%$ as fed) of experiment 2 diets

\begin{tabular}{|c|c|c|c|c|c|c|}
\hline \multirow[b]{2}{*}{ Ingredient } & \multicolumn{6}{|c|}{ Dietary protein } \\
\hline & $21 \%$ & $15 \%$ & $15 \%$ & $15 \%$ & $15 \%$ & $15 \%$ \\
\hline Casein & 23.57 & 16.38 & 16.70 & 16.66 & 16.60 & 16.61 \\
\hline Citric acid diamine & & 1.11 & & 0.69 & 0.80 & 1.53 \\
\hline Leu & & 1.75 & & & & \\
\hline Ile & & & 0.98 & & & \\
\hline Met & & & & 0.53 & & \\
\hline Thr & & & & & 0.77 & \\
\hline Corn starch & 37.57 & 40.47 & 41.25 & 41.15 & 41.01 & 41.02 \\
\hline Dextrin & 12.48 & 13.44 & 13.70 & 13.66 & 13.62 & 13.62 \\
\hline Sucrose & 11.39 & 12.26 & 12.50 & 12.47 & 12.42 & 12.43 \\
\hline Soybean oil & 6.99 & 6.81 & 6.94 & 6.92 & 6.90 & 6.90 \\
\hline Cellulose & 4.99 & 4.86 & 4.96 & 4.94 & 4.93 & 4.93 \\
\hline Mineral mix & 2.73 & 2.65 & 2.71 & 2.70 & 2.69 & 2.69 \\
\hline Vitamin mix & 0.026 & 0.025 & 0.026 & 0.026 & 0.026 & 0.026 \\
\hline Choline & 0.250 & 0.243 & 0.248 & 0.247 & 0.246 & 0.246 \\
\hline $\mathrm{TBHQ}^{1}$ & 0.0014 & 0.0014 & 0.0014 & 0.0014 & 0.0014 & 0.0014 \\
\hline
\end{tabular}

${ }^{1}$ Tert-butyl hydroquinone. 
were loaded in each well, separated by SDS-PAGE, and transferred to polyvinylidene fluoride membranes. The membranes were incubated in blocking buffer (Beyotime, P0023B, Jiangsu, China) at room temperature for $2 \mathrm{~h}$, and then probed for phosphorylated forms of mTOR (Ser2448), 4eBP1 (Thr37/46), S6K1 (Thr389), eEF2 (Thr56), eIF2 ${ }_{\alpha}$ (Ser51), and Akt (Ser473; catalog no. 2971, 9459, 2211, 2331, 9721, and 9271, respectively; Cell Signaling Technology, Danvers, MA). After primary antibody binding, the membranes were washed with Tris Buffered Saline Tween and probed with antirabbit secondary antibodies (Beyotime, A0208) bound to horse radish peroxidase, which diluted with the secondary antibody dilution buffer. Relative abundance of each protein was determined by chemiluminescence using a BeyoECL Plus kit (Beyotime). Relative band densities were determined using a Fusion Fx imaging system (Vilber, Marne-la-Valée, France) and associated software. Having determined relative abundance of phosphorylated proteins, the membranes were stripped using a commercial stripping solution (Fudebio-tech, P1050; Beyotime, P0025N) for $30 \mathrm{~min}$ and incubated in blocking buffer (Beyotime, P0023B) at room temp for $2 \mathrm{~h}$. The stripped membranes were subsequently probed for total mTOR, 4eBP1, S6K1, eEF2, and eIF2 $\alpha$ (catalog no. 2972, 9452, 2217, 2332, 9722, and 9272, respectively, Cell Signaling Technology).

Gene expression was measured by using real-time PCR. Briefly, total RNA was extracted using Trizol in mammary tissue from 6 mice per treatment group (Invitrogen, San Diego, CA). The quantity and quality (optical density at $260 / 280 \mathrm{~nm}=1.8-2.0$ ) of the isolated RNA were determined using a biophotometer (Eppendorf, Hamburg, Germany) and agarose gel electrophoresis for analyzing $28 \mathrm{~S}$ and $18 \mathrm{~S}$ rRNA subunits (Figure 1). The ratio of $28 \mathrm{~S}$ to $18 \mathrm{~S}$ was approximately $2: 1$, quantified using Fusion Fx software (Vilber). Reverse transcription was carried out using a room temperature reaction buffer $(10 \mu \mathrm{L})$, which consisted of $500 \mathrm{ng}$ of total RNA, 5 of mmol/L of $\mathrm{MgCl}_{2}, 1 \mu \mathrm{L}$ of room temperature buffer, $1 \mathrm{mmol} / \mathrm{L}$ of deoxynucleotide triphosphates, $2.5 \mathrm{U}$ of avian myeloblastosis virus, 0.7 $\mathrm{nmol} / \mathrm{L}$ of oligo $\mathrm{d}(\mathrm{T})$, and $10 \mathrm{U}$ of ribonuclease inhibitor (TaKaRa Biotechnology, Dalian, China). Ten nanograms of cDNA was amplified in $20 \mu \mathrm{L}$ of PCR reaction buffer containing $0.2 \mu \mathrm{mol} / \mathrm{L}$ of each specific primer (TaKaRa Biotechnology) and a SYBR green master mix (TaKaRa Biotechnology). Each cycle consisted of denaturation at $95^{\circ} \mathrm{C}$ for $10 \mathrm{~s}$, annealing, and extension at $60^{\circ} \mathrm{C}$ for $34 \mathrm{~s}$ (ABI7500, Applied Biosystems Inc., Waltham, MA). Glyceraldehyde-3-phosphate dehydrogenase was amplified as an internal control to normalize the differences in individual samples. The amplification efficiency of $\beta-C N, m T O R, S 6 K 1, e E F 2$, $e I F 2_{\alpha}$, and $G A P D H$ were $103,103,98,97,101$, and $100 \%$, respectively. The comparative cycle threshold (CT) method $\left(2^{-\Delta \Delta \mathrm{CT}}\right)$ was used to quantitate mRNA expression according to Livak and Schmittgen (2001). We used GAPDH as a housekeeping gene based on prior data from our laboratory showing that GAPDH is stably expressed and not affected by treatment in mammary tissue in lactating mice $(\mathrm{Wu}, 2014)$. The primer sequences for mice $\beta-C N, m T O R, S 6 K 1, e E F 2$, eIF2 $2_{\alpha}$, and $G A P D H$ are listed in Table 3.

\begin{tabular}{lcccccc}
\hline Dietary Protein & $21 \%$ & $15 \%$ & $15 \%$ & $15 \%$ & $15 \%$ & $15 \%$ \\
\hline Amino Acid & - & + Leu & + Ile & + Met & + Thr & -
\end{tabular}

Supplement

28s RNA
18s RNA

Figure 1. Representative agarose gel electrophoresis for total RNA from mammary tissue of lactating mice subjected to 2 levels of dietary protein $(15$ or $21 \%)$ and the low-protein diet supplemented with Leu, Ile, Met, or Thr. 
Table 3. Gene-specific primers used for mRNA expression measurements

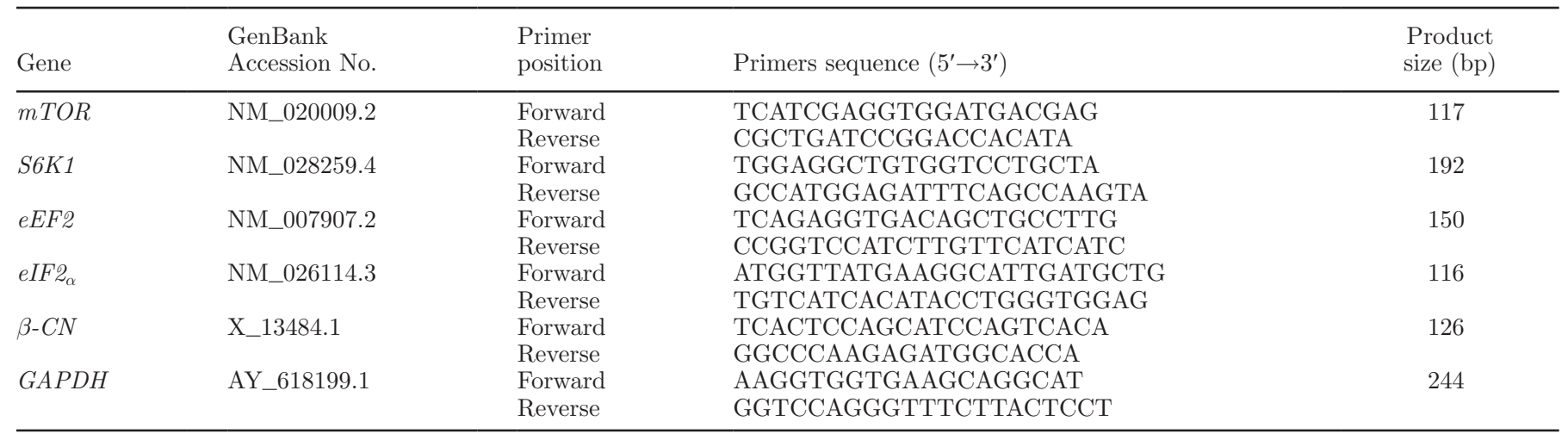

Adenosine triphosphatase activity in mammary tissue from 6 mice per treatment group was determined using an ATPase assay kit (Jiancheng, Nanjing, China). One hundred milligrams of mammary tissue from each mouse was homogenized in $0.9 \mathrm{~mL}$ of saline and centrifuged at 2,500 $\times g$ for $10 \mathrm{~min}$ at room temperature; $0.2 \mathrm{~mL}$ of the resulting supernate was combined with $0.8 \mathrm{~mL}$ of saline and a reagent solution (solutions are detailed in Table 4), and assessed for absorbance at 660 $\mathrm{nm}$ (optical density value) using a spectrophotometer. The ATPase activity of each ATPase (U/mg of protein) was determined as

$$
Y_{i}=\left(O D_{i}-O D_{c}\right) / O D_{s} \times C_{s} \times \text { dilution } \times 6 / C_{\text {sample }},
$$

where $Y_{i}=$ ATPase activity $\left(i=\mathrm{Na}^{+} \mathrm{K}^{+}\right.$-ATPase, $\mathrm{Ca}^{2+}$-ATPase, $\mathrm{Mg}^{2+}$-ATPase, $\mathrm{Ca}^{2+} \mathrm{Mg}^{2+}$-ATPase); $O D_{c}$ $=$ optical density value of the control sample; $O D_{s}=$ optical density value of the standard sample; $C_{s}=$ concentration of the standard sample $(1 \mu \mathrm{mol} / \mathrm{mL})$; dilution $=2.5$ times; $C_{\text {sample }}=$ protein concentration of the treatment sample ( $\mathrm{mg}$ of protein $/ \mathrm{mL}$ ). One unit of enzyme activity was defined as $1 \mathrm{mmol}$ of phosphorus released from $1 \mathrm{mg}$ of mammary tissue protein per hour. The sensitivity of the assay was $0.05 \mathrm{U} / \mathrm{mg}$. All samples were assessed in the same assay to avoid interassay variability. The interassay coefficient of variation was $5.64 \%$.

\section{Statistical Analysis}

The effects of dietary protein concentration on litter weight gain were analyzed using the ANOVA and NLIN procedures of SAS (version 9.2; SAS Institute Inc., Cary, NC). The ANOVA model was

$$
Y_{i j}=\mu+T_{i}+e_{i j}
$$

where $Y_{i j}=$ the litter weight gain $(\mathrm{g})$ of the $j$ th litter, $\mu$ $=$ the mean gain, $T_{i}=$ the fixed effect of diet $i(i=6$, $9,12,15,18,21,24$, or $27 \%$ protein), and $e_{i j}=$ random error of the $j$ th litter. Differences among treatment means were identified using Tukey's test. The NLIN model was

$$
\begin{gathered}
Y_{i j}=\operatorname{Max} W t \times\left(\mathrm{CP}_{i}-\text { maint }\right) / \\
{\left[K m+\left(\mathrm{CP}_{i}-\text { maint }\right)\right]+e_{i j}}
\end{gathered}
$$

Table 4. Constituents of reagent for ATPase detection ${ }^{1}$

\begin{tabular}{lrrrrr}
\hline Item $^{2}(\mu \mathrm{L})$ & A & B & C & D & E \\
\hline ATPase 1 & 130 & 130 & 90 & 130 & 90 \\
ATPase 2 & 40 & 40 & 40 & & 40 \\
ATPase 3 & & & & 40 & 40 \\
ATPase 4 & 40 & 40 & 40 & 40 & 40 \\
ATPase 5 & & & 40 & 40 & 40 \\
ATPase 6 & 40 & 40 & 40 & & 200 \\
Sample & 50 & 50 & 50 & 50 & 50 \\
ATPase $7^{3}$ & 200 & & & & \\
Sample & & & & & \\
\hline
\end{tabular}

${ }^{1}$ Reagent solutions A, B, C, D, or E were used to detect the optical density value of Control, $\mathrm{Na}^{+}, \mathrm{K}^{+2}, \mathrm{Ca}^{2+}$, $\mathrm{Mg}^{2+}$, or $\mathrm{Ca}^{2+} \mathrm{Mg}^{2+}$, respectively.

${ }^{2}$ ATPase 1 to 7 are kit solutions.

${ }^{3}$ Reagent solutions need water bath at $37^{\circ} \mathrm{C}$ for 10 min after finished mix ATPase 1-6. 
Table 5. Effect of maternal dietary protein on litter weight gain in mice ${ }^{1}$

\begin{tabular}{lcccccccccc}
\hline & \multicolumn{1}{c}{ Dietary protein } \\
\cline { 2 - 8 } Item & $6 \%$ & $9 \%$ & $12 \%$ & $15 \%$ & $18 \%$ & $21 \%$ & $24 \%$ & $27 \%$ & SEM & $P$-value \\
\hline Birth weight (g) & 14.41 & 14.36 & 13.70 & 14.64 & 14.35 & 14.47 & 14.18 & 14.70 & 1.11 & 0.81 \\
Litter weight gain (g) & $-14.41^{\mathrm{c}}$ & $-14.36^{\mathrm{c}}$ & $48.65^{\mathrm{b}}$ & $53.02^{\mathrm{b}}$ & $76.33^{\mathrm{a}}$ & $89.51^{\mathrm{a}}$ & $81.99^{\mathrm{a}}$ & $83.00^{\mathrm{a}}$ & 11.26 & $<0.001$ \\
Infanticide rate (\%) & 100 & 100 & 7.5 & 5 & 2.5 & 2.5 & 1.25 & 1.25 & \\
\hline
\end{tabular}

${ }^{\mathrm{a}-\mathrm{c}}$ Means with different letters are significantly different, $P<0.01$.

${ }^{1}$ Data are least squares means and pooled SEM, $\mathrm{n}=10,10,8,7,8,9,8,10$, respectively (dams with maternal death and pup death were removed).

where $Y_{i j}=$ the litter weight gain of the $j$ th litter, Max Wt $=$ the maximum litter weight gain, $\mathrm{CP}_{i}=$ the dietary $\mathrm{CP}$ content of diet $i(i=9,12,15,18,21$, 24 , or $27 \%$ protein), maint $=$ the dietary protein level required to achieve 0 litter weight gain, and $K m=$ the level of $\mathrm{CP}$ yielding half of the maximal growth response above maint.

In experiment 2 , the effects of diet on food intake, litter weight gain, gene expression, and ATPase activity were assessed using the following statistical model and the ANOVA procedure of SAS (version 9.2):

$$
Y_{i j}=\mu+T_{i}+e_{i j}
$$

where $Y_{i j}=$ the independent variable, $\mu=$ the mean, $T_{i}=$ the fixed effect of diet $i[i=21 \%$ protein, $15 \%$ protein $(\mathbf{L P}), \mathrm{LP}+\mathrm{Leu}, \mathrm{LP}+\mathrm{Ile}, \mathrm{LP}+$ Met, and $\mathrm{LP}+\mathrm{Thr}]$, and $e_{i j}=$ random error. Differences among treatment means were identified using Tukey's test.

Signaling proteins were analyzed using the MIXED procedure of SAS (version 9.2) and the model was

$$
Y_{i j}=\mu+T_{i}+G_{j}+e_{i j}
$$

where $Y_{i j}=$ total protein, phosphorylated protein, or phosphorylated protein/total protein; $\mu=$ the mean; $T_{i}$ $=$ the fixed effect of diet $i ; G_{j}=$ random effect of gel; and $e_{i j}=$ random error. Differences among treatment means were identified using the Tukey's test.

Simple linear relationships between litter weight gains and phosphorylation ratios of signaling proteins were determined using the REG procedure of SAS (version 9.2). Litter weight gains were also regressed on phos- phorylation of all 6 signaling proteins using a multiple linear regression model and backward elimination with a threshold $P$-value of 0.05 .

\section{RESULTS}

\section{Litter Weight Gain, Infanticide, and Food Intake}

In the first experiment, litter weight gain was affected by dietary protein $(P<0.01)$ at concentrations less than $18 \%$. All of the pups in litters of dams given the 6 or $9 \%$ protein diets were cannibalized in the first week of the trial (Table 5). Above those levels, the infanticide rates generally declined as dietary protein increased and were less than $5 \%$ for diets above $21 \%$ protein. The half-maximal litter growth rate was achieved at $16.5 \%$ protein, and the maximal litter weight gain was $177 \mathrm{~g}$ (Table 6 and Figure 2).

In experiment 2 , we noted a trend for reduced food intake for the Met and Thr treatments $(P=0.06$, Table 7 ). Litter weight gain for the $21 \%$ protein diet was $19 \%$ greater than for the low-protein group, demonstrating a protein deficiency, as predicted from experiment 1 . Supplementation of the low-protein diet with Ile, Leu, or Met increased $(P<0.01)$ litter weight gain by 11 , 9 , or $10 \%$, respectively, as compared with the proteindeficient diet.

\section{ATPase Activity}

Each of the 4 ATPase enzymes assessed had similar rates of activity of approximately $5 \mathrm{U} / \mathrm{mg}$ of protein, with a standard error of the mean ranging from a low

Table 6. Modeling the effect of maternal dietary protein on litter growth rates

\begin{tabular}{lcccc}
\hline Parameter & Estimate & SE & Skewness & $P$-value \\
\hline Maximum weight $(\mathrm{g})$ & 177 & 72 & 2.87 & 0.002 \\
Km $^{1}$ & 16.5 & 11.5 & 3.22 & 0.002 \\
Maint $^{2}$ & 7.9 & 0.80 & -0.18 & 0.002 \\
\hline
\end{tabular}

${ }^{1} \mathrm{Km}=$ the level of $\mathrm{CP}$ yielding half the maximal growth response above maint.

${ }^{2}$ Maint $=$ the dietary protein level required to achieve zero litter weight gain. 
Table 7. Effect of maternal dietary protein and Leu, Ile, Met, and Thr supplementation on dam food intake and litter weight gain in mice ${ }^{1}$

\begin{tabular}{lcccccccc}
\hline & \multicolumn{7}{c}{ Dietary protein (AA supplement) } \\
\cline { 2 - 7 } Item & $15 \%$ & $15 \%($ Leu $)$ & $15 \%($ Ile) & $15 \%($ Met) & $15 \%($ Thr) & $21 \%$ & SEM & $P$-value \\
\hline Food intake (g/d) & $13.04^{\mathrm{a}}$ & $12.54^{\mathrm{ab}}$ & $13.13^{\mathrm{a}}$ & $12.06^{\mathrm{b}}$ & $12.09^{\mathrm{b}}$ & $12.78^{\mathrm{ab}}$ & 1.26 \\
Birth weight (g) & 15.45 & 15.42 & 15.39 & 14.92 & 15.53 & 14.77 & 1.38 & 0.061 \\
Litter weight gain (g/17 d) & $67.10^{\mathrm{c}}$ & $77.63^{\mathrm{b}}$ & $77.17^{\mathrm{b}}$ & $78.22^{\mathrm{b}}$ & $69.09^{\mathrm{c}}$ & $85.06^{\mathrm{a}}$ & 9.58 & $<0.001$ \\
Infanticide rate (\%) & 5.63 & 6.88 & 1.88 & 5 & 6.88 & 1.25 & \\
\hline
\end{tabular}

${ }^{\mathrm{a}-\mathrm{c}}$ Means with different letters are significantly different, $P<0.01$.

${ }^{1}$ Data are least squares means and pooled $\mathrm{SEM}, \mathrm{n}=17,18,18,18,16$, and 19 for each dietary protein level, respectively (dams with maternal death and pup death).

of 1.24 for $\mathrm{Na}^{+} \mathrm{K}^{+}$-ATPase to a high of 1.83 for $\mathrm{Ca}^{2+}$ $\mathrm{Mg}^{2+}$-ATPase. Supplementation of individual EAA had no significant effects on mammary $\mathrm{Na}^{+} \mathrm{K}^{+}$-ATPase, $\mathrm{Mg}^{2+}$-ATPase, $\mathrm{Ca}^{2+}$-ATPase, or $\mathrm{Ca}^{2+} \mathrm{Mg}^{2+}$-ATPase (Table 8).

\section{Gene Expression in Mammary Tissue}

The expression of $\beta-C N$ mRNA was enhanced ( $P$ $<0.01$ ) in mammary tissue with supplementation of individual EAA. The most significant increase in $\beta-C N$ mRNA expression was observed in mice supplied with $21 \%$ protein, followed by mice supplemented with Met $(P<0.01)$. Individual EAA treatments also significantly increased mRNA abundance (Table 9) of $m$ TOR $(P<0.01)$, S6K1 $(P<0.01)$, and eEF2 $(P<0.01)$. We found no significant differences in eIF2 $\alpha$ mRNA expression associated with EAA treatments.

\section{Cell Signaling Protein Phosphorylation in Mammary Tissue}

Supplementation of Ile, Leu, Met, and Thr increased $(P<0.05)$ the ratio of phosphorylated over total mTOR by $55,34,47$, and $45 \%$, respectively, compared with the low-protein group (Table 10). The phosphorylation ratio for mTOR was also increased $(P<0.05)$ by $58 \%$ for the high-protein group compared with low-protein group. The phosphorylated to total ratio of $4 \mathrm{eBP} 1$ also increased in response to Ile, Met, and Thr supplementation by 60,40 , and $51 \%$, respectively $(P<0.01)$. Phosphorylation ratios of $4 \mathrm{eBP} 1$ were only numerically increased for the high-protein and Leu treatments. Supplementation of Ile and Met increased $(P<0.01)$ the ratio of phosphorylated over total Akt/protein kinase B (Akt) by 41 and $59 \%$, respectively, compared with the low-protein group. We observed no differences in the phosphorylated to total ratios of S6K1, eEF2, and eIF $2_{\alpha}$ associated with EAA supplementation.

Litter weight gain was correlated with mTOR $(P$ $<0.01)$ and S6K1 $(P<0.01)$ phosphorylation ratios.
However, the correlation was stronger for the relationship between litter weight gain, and mTOR and Akt enhanced the response when the data were assessed by multiple linear regressions using backward elimination (Table 11).

\section{DISCUSSION}

\section{Single AA Effects on Animal Performance}

The first experiment clearly established that lactational performance of mice, as measured by litter growth rates, was responsive in a nonlinear manner to dietary protein with a maximal litter growth rate of 177 g over $17 \mathrm{~d}$. This gain represents $34 \%$ of dam BW. The infanticide rate increased as dietary protein became

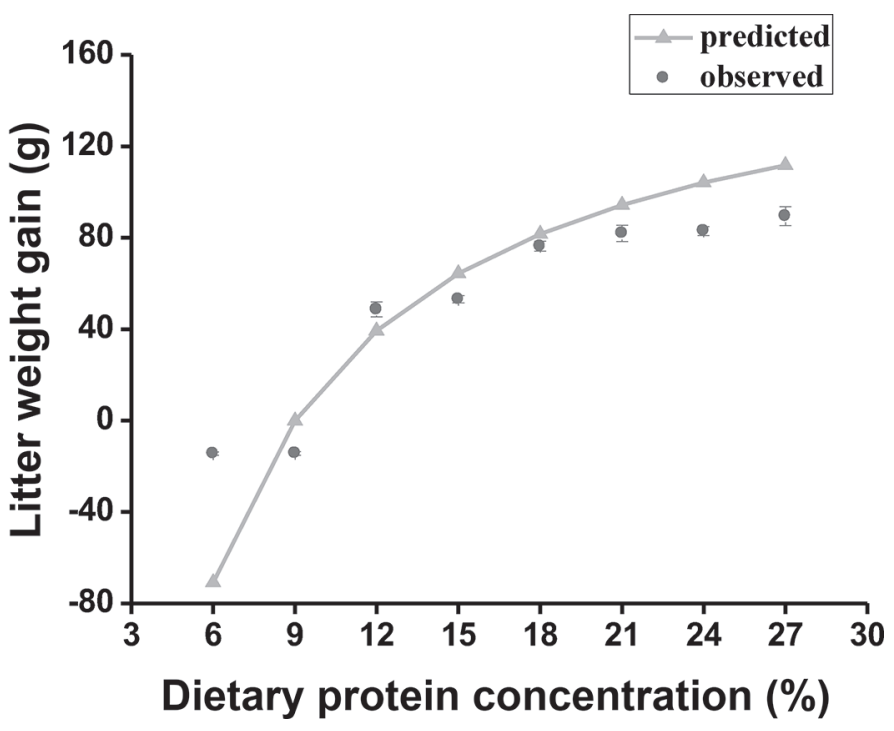

Figure 2. Effect of maternal dietary protein concentration on litter weight gain in mice. The predicted line was derived by fitting a Michealis-Menten equation to the data with the formulated $\mathrm{CP}$ concentrations as the independent variable. $\mathrm{n}=10,10,8,7,8,9,8$, and 10 for each treatment, respectively. Error bars indicate the SD of the observed value. 
Table 8. Effect of maternal dietary protein and Leu, Ile, Met, and Thr supplementation on mammary ATPase activity in lactating mice ${ }^{1}$

\begin{tabular}{|c|c|c|c|c|c|c|c|c|}
\hline Item (U/mg of protein) & \multicolumn{6}{|c|}{ Dietary protein (AA supplement) } & SEM & $P$-value \\
\hline $\mathrm{Na}^{+} \mathrm{K}^{+}$-ATPase & 5.3 & 6.1 & 6.4 & 6.2 & 5.3 & 5.2 & 1.24 & 0.39 \\
\hline $\mathrm{Ca}^{2+}$-ATPase & 4.8 & 6.5 & 6.1 & 6.1 & 5.6 & 5.0 & 1.47 & 0.28 \\
\hline $\mathrm{Ca}^{2+} \mathrm{Mg}^{2+}$-ATPase & 4.8 & 5.6 & 6.0 & 6.0 & 5.3 & 5.1 & 1.83 & 0.81 \\
\hline
\end{tabular}

${ }^{1}$ Data are least squares means and pooled SEM, $\mathrm{n}=6$.

more limiting, reaching $100 \%$ when protein concentrations were less than $12 \%$. The results showed that the half-maximal litter growth rate over maintenance was achieved at $16.5 \%$ protein.

The curvilinear nature of the response to dietary protein does not adhere to the often used linear, break-point model to define nutrient requirements (NRC, 2001). It has been argued that the linear model is still appropriate, as the curvature is created by genetic diversity for requirements within the population of animals under study (Fisher et al., 1973; Gurnow, 1973). However, in a Latin square design, Whitelaw et al. (1986) observed clear diminishing returns to abomasally infused caseins, which mimics the population observations by Lapierre et al. (2007). Both linear and Latin square match the response curves observed herein with a highly inbred, and thus genetically homogeneous, line of mice. Thus, little if any evidence supports the use of a linear, breakpoint model to define at least protein and AA requirements for lactation, and use of such models will clearly under-predict true maximal response and yield inaccurate marginal responses to increasing nutrient supply as the system approaches saturation (Gahl et al., 1994).

Methionine, Ile, and Leu independently influenced litter growth rates which are consistent with milk protein synthesis observations from bovine mammary tissue (Appuhamy, 2010; Appuhamy et al., 2012). It was also reported that Trp, Met, Cys, and Thr each individually stimulated milk protein synthesis in bovine mammary explant cultures (Clark et al., 1978). These results are in conflict with the single-limiting AA theory laid out by Mitchell and Block (1946). That concept is an application of the Law of the Minimum proposed by von Liebig (1863) to explain growth responses of field crops to mineral fertilizers. As applied, the theory states that even if several EAA are deficient in supply, only supplementation with the most deficient EAA will improve protein gain. Amino acid requirement systems have all been constructed according to this theory, but the results herein and prior in vitro results (Appuhamy et al., 2012; Clark et al., 1978) refute the application of that theory for predicting milk protein responses necessitating an alternative conceptual framework for our lactational $\mathrm{AA}$ requirement systems. Consistent with these observations, inclusion of a representation of the independent and additive effects of His, Lys, Met, Phe, and Thr in a model of bovine mammary metabolism greatly improved model accuracy and precision (Hanigan et al., 2000). More recently, a model integrating in vitro data also demonstrated the independent effects of at least Leu and Ile (Castro et al., 2016). At the wholeanimal level, adoption of a revised conceptual framework within the NRC (2001) dairy model that represents the independent and additive effects of all of the individual EAA greatly improved model accuracy and precision as compared with a linear model with single-limiting AA (White et al., 2016a), and a similar change in the NRC (2012) swine lactation model resulted in a similar

Table 9. Effect of maternal dietary protein and Leu, Ile, Met, and Thr supplementation on mammary gene mRNA expression in lactating mice ${ }^{1}$

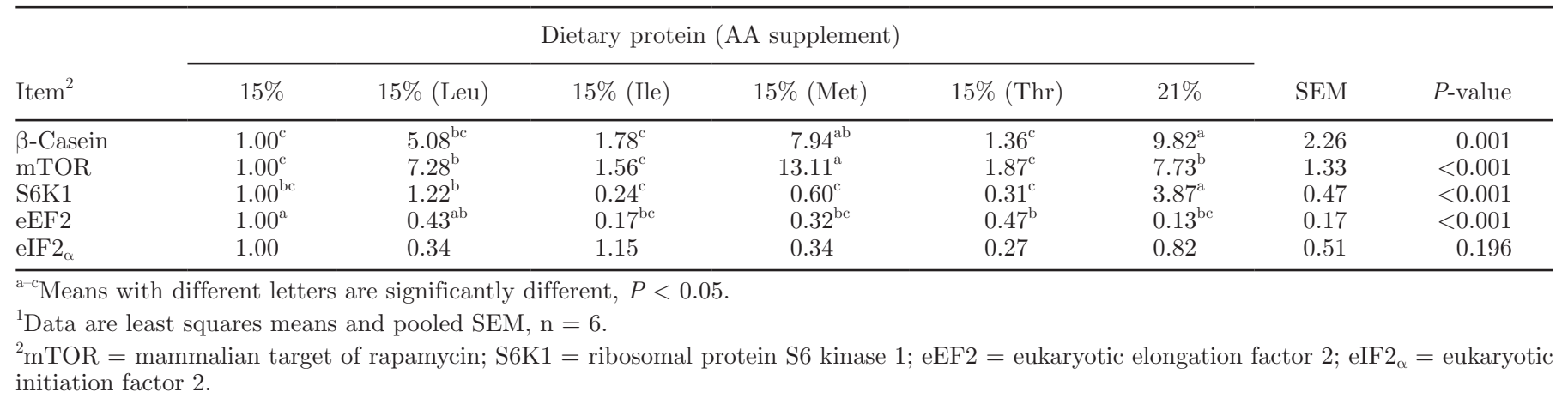


Table 10. Effect of dietary protein and Leu, Ile, Met, and Thr supplementation on mammary cell signaling protein expression (T) and phosphorylation $(\mathrm{P})$ or the ratio of phosphorylated to total in lactating mice ${ }^{1}$

\begin{tabular}{|c|c|c|c|c|c|c|c|c|}
\hline \multirow[b]{2}{*}{ Item $^{2}$} & \multicolumn{6}{|c|}{ Dietary protein (AA supplement) } & \multirow[b]{2}{*}{ SEM } & \multirow[b]{2}{*}{$P$-value } \\
\hline & $15 \%$ & $15 \%(\mathrm{Leu})$ & $15 \%$ (Ile) & $15 \%$ (Met) & $15 \%(\mathrm{Thr})$ & $21 \%$ & & \\
\hline P-mTOR & 0.77 & 0.89 & 0.95 & 1.14 & 1.15 & 1.10 & 0.11 & 0.112 \\
\hline T-mTOR & 1.08 & 0.82 & 0.99 & 1.18 & 1.13 & 0.98 & 0.13 & 0.469 \\
\hline P-mTOR/T-mTOR & $0.73^{\mathrm{b}}$ & $1.15^{\mathrm{a}}$ & $0.98^{\mathrm{a}}$ & $1.07^{\mathrm{a}}$ & $1.06^{\mathrm{a}}$ & $1.13^{\mathrm{a}}$ & 0.09 & 0.029 \\
\hline P-4eBP1 & 0.81 & 1.04 & 1.3 & 0.85 & 1.1 & 0.88 & 0.16 & 0.223 \\
\hline $\mathrm{T}-4 \mathrm{eBP} 1$ & 1.06 & 1.32 & 1.05 & 0.83 & 1.00 & 1.00 & 0.13 & 0.208 \\
\hline $\mathrm{P}-4 \mathrm{eBP} 1 / \mathrm{T}-4 \mathrm{eBP} 1$ & $0.75^{\mathrm{b}}$ & $0.82^{\mathrm{b}}$ & $1.2^{\mathrm{a}}$ & $1.05^{\mathrm{ab}}$ & $1.13^{\mathrm{a}}$ & $0.91^{\mathrm{b}}$ & 0.09 & 0.007 \\
\hline P-S6K1 & 1.04 & 1.04 & 0.96 & 1.16 & 0.90 & 1.25 & 0.16 & 0.657 \\
\hline T-S6K1 & 1.11 & 1.1 & 0.90 & 1.03 & 0.93 & 1.1 & 0.15 & 0.831 \\
\hline P-S6K1/T-S6K1 & 0.91 & 0.97 & 1.1 & 1.3 & 0.99 & 1.22 & 0.10 & 0.313 \\
\hline P-eEF2 & 0.95 & 0.84 & 0.77 & 1.21 & 0.96 & 1.12 & 0.18 & 0.529 \\
\hline T-eEF2 & 1.05 & 0.86 & 0.93 & 1.32 & 1.20 & 1.03 & 0.18 & 0.486 \\
\hline P-eEF2/ T-eEF2 & 0.93 & 0.94 & 0.85 & 0.95 & 0.83 & 1.04 & 0.10 & 0.679 \\
\hline P-eIF $2_{\alpha}$ & 1.28 & 1.02 & 0.98 & 0.86 & 1.14 & 1.12 & 0.15 & 0.496 \\
\hline $\mathrm{T}-\mathrm{eIF} 2_{\alpha}$ & 1.23 & 0.96 & 1.00 & 0.93 & 1.28 & 1.10 & 0.16 & 0.538 \\
\hline $\mathrm{P}-\mathrm{eIF} 2_{\alpha} / \mathrm{T}-\mathrm{eIF} 2_{\alpha}$ & 1.08 & 1.07 & 1.03 & 0.96 & 0.93 & 1.03 & 0.09 & 0.833 \\
\hline P-Akt & 0.84 & 1.10 & 1.13 & 1.08 & 1.09 & 1.08 & 0.33 & 0.523 \\
\hline $\mathrm{T}-\mathrm{Akt}$ & 1.10 & 1.15 & 1.12 & 0.91 & 1.12 & 0.84 & 0.33 & 0.332 \\
\hline P-Akt/T-Akt & $0.76^{\mathrm{c}}$ & $0.98^{\mathrm{bc}}$ & $1.07^{\mathrm{ab}}$ & $1.21^{\mathrm{a}}$ & $0.96^{\mathrm{bc}}$ & $1.29^{\mathrm{a}}$ & 0.22 & $<0.001$ \\
\hline
\end{tabular}

${ }^{\mathrm{a}-\mathrm{c}}$ Means with different letters are significantly different, $P<0.05$.

${ }^{1}$ Data are least squares means and pooled SEM, $\mathrm{n}=8$.

${ }^{2} \mathrm{mTOR}=$ mammalian target of rapamycin; 4eBP1 = eIF4E binding protein 1; S6K1 = ribosomal protein S6 kinase 1; eEF2 = eukaryotic elongation factor 2 ; eIF $2_{\alpha}=$ eukaryotic initiation factor 2 ; Akt $=$ protein kinase $\mathrm{B}$.

improvement in model accuracy and precision (White et al., 2016b). Thus, evidence supporting the dismissal of the conceptual framework laid out by Mitchell and Block (1946) for application to lactation exists at the cellular, whole tissue, and animal levels for multiple species. Although a Michaelis-Menten equation form has been used in previous modeling work, it is by no means certain that is the best functional form to repre- sent the system. Clearly it works much better than the Mitchell and Block (1946) framework, but that does not preclude the existence of a better representation.

\section{Cell Signaling Protein Phosphorylation}

The mTOR pathway revolves around the mTOR complex 1 (Mahoney et al., 2009). In complex 1, mTOR

Table 11. Regression of litter weight gain on mammary signaling protein phosphorylation of lactating mice fed diets with varying dietary protein and supplemented with Leu, Ile, Met, or Thr ${ }^{1}$

\begin{tabular}{lcrl}
\hline Phosphorylation ratio & Regression coefficient & $P$-value & $\mathrm{R}^{2}$ \\
\hline Simple linear regressions & & & \\
mTOR & 0.60 & $<0.001$ & 0.36 \\
4eBP1 & 0.19 & 0.201 & 0.04 \\
S6K1 & 0.39 & 0.006 & 0.15 \\
eEF2 & 0.06 & 0.692 & 0.003 \\
eIF2 & -0.14 & 0.332 & 0.02 \\
Akt & 0.31 & 0.031 & 0.09 \\
Multiple linear regression-Full model & & 0.001 & 0.45 \\
mTOR & 0.49 & 0.709 & \\
4eBP1 & 0.06 & 0.158 & \\
S6K1 & 0.18 & 0.985 & \\
eEF2 & 0.002 & 0.482 & \\
eIF2 & -0.10 & 0.118 & \\
Akt & 0.19 & $<0.001$ & 0.40 \\
Multiple linear regression-Reduced model & & 0.064 & \\
mTOR & 0.60 & & \\
Akt & 0.22 & \multicolumn{2}{c}{} \\
\hline
\end{tabular}

${ }^{1} \mathrm{mTOR}=$ mammalian target of rapamycin; 4eBP1 = eIF4E binding protein 1; S6K1 = ribosomal protein $\mathrm{S} 6$ kinase 1 ; eEF2 = eukaryotic elongation factor 2 ; eIF $2_{\alpha}=$ eukaryotic initiation factor 2 ; Akt $=$ protein kinase $\mathrm{B}$. 


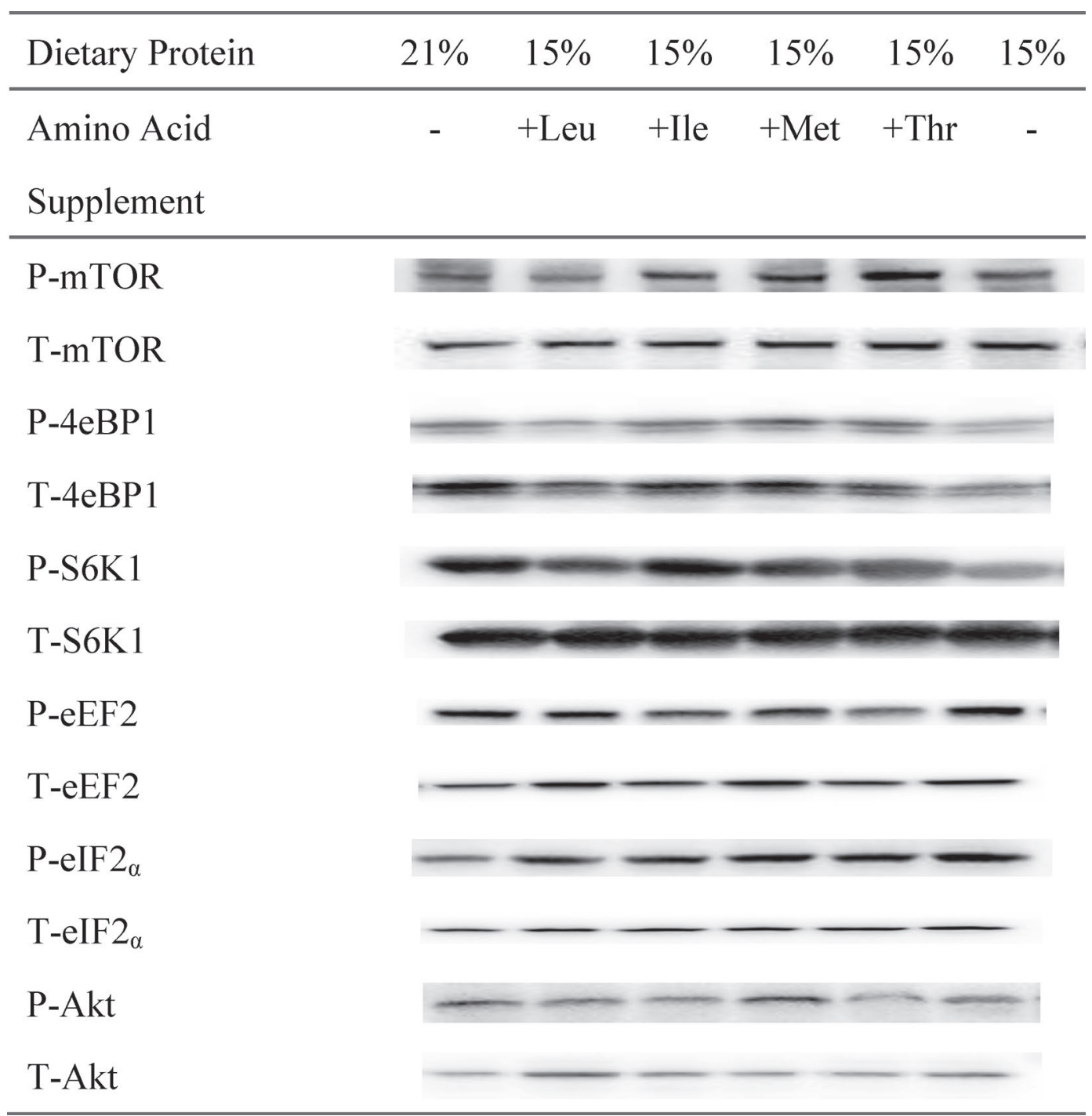

Figure 3. Representative immunoblots of phosphorylated $(\mathrm{P})$ and total $(\mathrm{T})$ forms of signaling proteins from mammary tissue of lactating mice subjected to 2 levels of dietary protein (15 or 21\%) and the low-protein diet supplemented with Leu, Ile, Met, or Thr. mTOR $=$ mammalian target of rapamycin; $4 \mathrm{eBP} 1=\mathrm{eIF} 4 \mathrm{E}$ binding protein $1 ; \mathrm{S} 6 \mathrm{~K} 1=$ ribosomal protein S6 kinase 1; eEF2 = eukaryotic elongation factor $2 ;$ eIF $2_{\alpha}=$ eukaryotic initiation factor 2 ; Akt $=$ protein kinase $\mathrm{B}$.

plays a key role in regulating the phosphorylation of several components of the translational machinery. Phosphorylated and activated of mTOR controls the translation of mRNA in a specific subgroup (Chiang and Abraham, 2005) through the 4eBP1 and p70S6K pathways downstream pathways (Dunlop and Tee, 2009; Mahoney et al., 2009). These pathways appear to be the primary controls of translational rates (Moshel et al., 2006).

Burgos et al. (2010) reported declines in mTOR signaling and FSR in bovine mammary acini when medium were devoid of total EAA. Amino acid-induced stimulation of protein synthesis is known to be at least partially mediated by mTOR (Kim, 2009). In the present study, supplementation of Ile and Leu increased the ratio of phosphorylated over total mTOR by 55 and $34 \%$, respectively, as compared with the low-protein group, which is consistent with prior work in mammary tissue (Appuhamy et al., 2012). The strong correlation between litter weight gain and mTOR indicated that individual EAA regulated protein synthesis rates through cell signaling pathways in lactating mice. The present results (Figure 3) indicated that all 4 EAA tested substantially influenced the mTOR signaling pathway phosphorylation state, and that these changes were mostly reflected in changes in milk protein syn- 
thesis excepting Thr. The almost identical litter weight gain responses to the addition of Ile, Leu, and Met suggest that these AA had equal potency, which is not completely consistent with the strong Ile and Leu effects observed by Castro et al. (2016).

Often, $4 \mathrm{eBP} 1$ is used as an indicator of mTOR complex 1 activity (Avruch et al., 2009), which mediates phosphorylation of $4 \mathrm{eBP} 1$, causing it to release eIF4E to form the eIF4F translation initiation complex. Phosphorylation of the Thr37/46 site is considered a marker of 4eBP1 hyperphosphorylation (Gingras et al., 2001); therefore, 4eBP1 phosphorylation at Thr37/46 should be an indicator of translation initiation rates. However, 4eBP1 phosphorylation only responded to supplementation of Ile and Thr and we found no difference in the high- and low-protein diets, whereas milk protein synthesis responded to total protein, Leu, Ile, and Met, but not Thr. This disparity in 4e-BP1 phosphorylation and milk protein synthesis, as reflected in litter growth rates, is consistent with the lack of a correlation in the regression results. The response to Leu was consistent with in vitro observation of both phosphorylation of 4e-BP1 and FSR in bovine mammary epithelial cells (Moshel et al., 2006).

Phosphorylation of S6K1 was correlated with litter weight gain by simple linear regression, but there was no correlation when multiple linear regressions were performed; S6K1 is thought to be directly phosphorylated by mTOR (Appuhamy et al., 2011a), and Appuhamy et al. (2012) previously observed a positive correlation between S6K1 phosphorylation and mTOR phosphorylation. The lack of a correlation in the multiple regressions likely reflects a high correlation between mTOR and S6K1 phosphorylation, resulting in only 1 regression needed to explain the response in litter weight gain.

Phosphorylation of eEF2 at Thr56 by eEF2 kinase inhibits the elongation step of mRNA translation (Ryazanov et al.,1988); eEF2 kinase activity was inversely associated with mTOR activity (Redpath et al., 1996). The link between mTOR and eEF2 kinase is mediated via S6K1 (Proud, 2004). In mammary tissue, eEF2 phosphorylation was previously found to be negatively correlated with FSR, but eEF2 phosphorylation was not associated with mTOR phosphorylation (Appuhamy et al., 2012). Others also observed eEF2 phosphorylation to be inversely related to EAA supply (Orellana et al., 2007; Suryawan et al., 2008; Appuhamy et al., 2012) where we failed to observe a response to total protein in the diet.

The translation initiation factor eIF $2 \alpha$ plays a critical role in regulating global translation rates by promoting recruitment of initiator methionyl-transfer RNA to the
$40 \mathrm{~S}$ ribosomal subunit. It was demonstrated that cellular stresses, such as AA deprivation, cause enhanced phosphorylation of eIF $2 \alpha$ at Ser51, which inhibited translation initiation (Anthony et al., 2004). Among known eIF2 kinases, the general control nonrepressible kinase 2 (GCN2) has been shown to be responsible for AA mediated phosphorylation of eIF $2 \alpha$ in mouse embryonic stem cells (Harding et al., 2000). Although our data and other observations clearly indicate that several EAA must additively influence translation in mammary cells, with no single EAA playing a predominant role (Appuhamy et al., 2012), we observed no differences in the phosphorylated-to-total ratios of eIF2 in the current work. The lack of responses in eIF $2 \alpha$ phosphorylation suggests that the GCN2 pathway is not the primary mediator of AA effects on milk protein synthesis in mammary tissue in vivo.

\section{EAA Effects on Gene Expression}

In addition to the apparent effects of EAA and high protein on translational rates, the Leu, Met, and highprotein treatments were associated with significant increases in casein and mTOR mRNA abundance, suggesting that more template was available for translation in each case. However, in the case of mTOR, the observed increases in mRNA abundance did not appear to translate to an increase in the total protein expressed in the cell. Total mTOR protein levels were relatively constant across treatments. Abundance of S6K1 mRNA was increased in the high-protein diet, but the increased abundance did not result in an increase in the total $\mathrm{S} 6 \mathrm{~K} 1$ protein expression for mTOR. Expression of eEF2 mRNA was reduced for the Ile, Met, and high-protein treatments; however, the protein expression levels were not significantly affected by treatment. Given the lack of concordance between mRNA expression levels and protein concentrations in the cell, it is difficult to interpret the mRNA expression data.

\section{CONCLUSIONS}

The results of our study indicated that milk production responses to supplementation of Ile, Leu, and Met are independent and do not adhere to the concept of a single-limiting AA. The independence of these responses are further supported by the independent responses of mTOR pathway signaling to individual EAA supplementation. The lack of responses in eIF2 $\alpha$ phosphorylation suggested that the GCN2 pathway is not the primary mediator of AA effects on milk protein synthesis. Incorporation of a multiple-limiting AA 
concept into milk protein response models will help improve milk and milk protein yield predictions, thus allowing derivation of diets that will result in increased postabsorptive $\mathrm{N}$ efficiency and reduced $\mathrm{N}$ excretion by dairy animals.

\section{ACKNOWLEDGMENTS}

This project was supported by the National Natural Science Foundation of China (31072050, 31372340), Modern Agro-industry Technology Research System of China (CARS-37; Beijing, China).

\section{REFERENCES}

Anthony, J. C., C. H. Lang, S. J. Crozier, T. G. Anthony, D. A. MacLeam, S. R. Kimball, and L. S. Jefferson. 2002. Contribution of insulin to the translational control of protein synthesis in skeletal muscle by leucine. Am. J. Physiol. Endocrinol. Metab. 282:E1092E1101.

Anthony, T. G., B. J. McDaniel, R. L. Byerley, B. C. McGrath, D. R. Cavener, M. A. McNurlan, and R. C. Wek. 2004. Preservation of liver protein synthesis during dietary leucine deprivation occurs at the expense of skeletal muscle mass in mice deleted for eIF2 kinase GCN2. J. Biol. Chem. 279:36553-36561.

Appuhamy, J. A. D. R. N. 2010. Regulatory roles of essential amino acids, energy, and insulin in mammary cell protein synthesis. $\mathrm{PhD}$ Diss. Virginia Polytechnic Institute and State University, Blacksburg.

Appuhamy, J. A. D. R. N., A. L. Bell, W. A. D. Nayananjalie, J. Escobar, and M. D. Hanigan. 2011a. Essential amino acids regulate both initiation and elongation of mRNA translation independent of insulin in MAC-T cells and bovine mammary tissue slices. J. Nutr. 141:1209-1215.

Appuhamy, J. A. D. R. N., N. A. Knoebel, W. A. D. Nayananjalie, J. Escobar, and M. D. Hanigan. 2012. Isoleucine and leucine independently regulate mTOR signaling and protein synthesis in MAC-T cells and bovine mammary tissue slices. J. Nutr. 142:484-491.

Arriola Apelo, S. I., L. M. Singer, X. Y. Lin, M. L. McGilliard, N. R. St-Pierre, and M. D. Hanigan. 2014. Isoleucine, leucine, methionine, and threonine effects on mammalian target of rapamycin signaling in mammary tissue. J. Dairy Sci. 97:1047-1056.

Avruch, J., X. Long, S. Ortiz-Vega, J. Rapley, A. Papageorgiou, and N. Dai. 2009. Amino acid regulation of TOR complex 1. Am. J. Physiol. Endocrinol. Metab. 296:E592-E602.

Bequette, B. J., C. E. Kyle, L. A. Crompton, V. Buchan, and M. D. Hanigan. 2001. Insulin regulates milk production and mammary gland and hind-leg amino acid fluxes and blood flow in lactating goats. J. Dairy Sci. 84:241-255.

Burgos, S. A., M. Da, and J. P. Cant. 2010. Nutrient availability and lactogenic hormones regulate mammary protein synthesis through the mammalian target of rapamycin signaling pathway. J. Dairy Sci. 93:153-161.

Castro, J. J., S. A. Apelo, J. A. D. R. N. Appuhamy, and M. D. Hanigan. 2016. Development of a model describing regulation of casein synthesis by the mammalian target of rapamycin (mTOR) signaling pathway in response to insulin, amino acids, and acetate. J. Dairy Sci. 99:6714-6736.

Chiang, G. G., and R. T. Abraham. 2005. Phosphorylation of mammalian target of rapamycin (mTOR) at Ser-2448 is mediated by p70S6 kinase. J. Biol. Chem. 280:25485-25490.

Christophersen, C. T., J. Karlsen, M. O. Nielsen, and B. Riis. 2002. Eukaryotic elongation factor-2 (EEF-2) activity in bovine mammary tissue in relation to milk protein synthesis. J. Dairy Res. 69:205-212.
Clark, R. M., P. T. Chandler, and C. S. Park. 1978. Limiting amino acids for milk protein synthesis by bovine mammary cells in culture. J. Dairy Sci. 61:408-413.

Dunlop, E. A., and A. R. Tee. 2009. Mammalian target of rapamycin complex 1: Signalling inputs, substrates and feedback mechanisms. Cell. Signal. 21:827-835.

Escobar, J., J. W. Frank, A. Suryawan, N. H. V. Guyen, S. R. Kimball, L. S. Jefferson, and T. A. Davis. 2006. Regulation of cardiac and skeletal muscle protein synthesis by individual branched-chain amino acids in neonatal pigs. Am. J. Physiol. Endocrinol. Metab. 290:E612-E621.

Fisher, C., T. R. Morris, and R. C. Jennings. 1973. A model for the description and prediction of the response of laying hens to amino acid intake. Br. Poult. Sci. 14:469-484.

Gahl, M. J., T. D. Crenshaw, and N. J. Benevenga. 1994. Diminishing returns in weight, nitrogen, and lysine gain of pigs fed six levels of lysine from three supplemental sources. J. Anim. Sci. $72: 3177-3187$.

Gingras, A. C., B. Raught, S. P. Gygi, A. Niedzwiecka, M. Miron, S. K. Burley, R. D. Polakiewicz, A. Wyslouch-Cieszynska, R. Aebersold, and N. Sonenberg. 2001. Hierarchical phosphorylation of the translation inhibitor 4E-BP1. Genes Dev. 15:2852-2864.

Gurnow, R. N. 1973. A smooth population response curve based on an abrupt threshold and planteau model for individuals. Biometrics $29: 1-10$.

Hanigan, M. D., J. P. Cant, D. C. Weakley, and J. L. Beckett. 1998. An evaluation of postabsorptive protein and amino acid metabolism in the lactating dairy cow. J. Dairy Sci. 81:3385-3401.

Hanigan, M. D., J. France, L. A. Crompton, and B. J. Bequette. 2000. Evaluation of a Representation of the Limiting Amino Acid Theory for Milk Protein Synthesis. CABI, Wallingford, UK.

Harding, H. P., I. Novoa, Y. Zhang, H. Zeng, R. Wek, M. Schapira, and D. Ron. 2000. Regulated translation initiation controls stress-induced gene expression in mammalian cells. Mol. Cell 6:1099-1108.

Kebreab, E., J. France, D. E. Beever, and A. R. Castillo. 2001. Nitrogen pollution by dairy cows and its mitigation by dietary manipulation. Nutr. Cycl. Agroecosyst. 60:275-285.

Kim, E. 2009. Mechanisms of amino acid sensing in mTOR signaling pathway. Nutr. Res. Pract. 3:64-71.

Kimball, S. R. 2001. Regulation of translation initiation by amino acids in eukaryotic cells. Prog. Mol. Subcell. Biol. 26:155-184.

Kimball, S. R., and L. S. Jefferson. 2006. New functions for amino acids: effects on gene transcription and translation. Am. J. Clin. Nutr. 83:S500-S507.

Lapierre, H., G. E. Lobley, D. R. Ouellet, L. Doepel, and D. Pacheco. 2007. Amino acid requirements for lactating dairy cows: Reconciling predictive models and biology. Pages 39-59 in Proc. Cornell Nutrition Conference for Feed Manufacturers. Dept. of Anim. Sci., Cornell Univ., New York.

Livak, K. J., and T. D. Schmittgen. 2001. Analysis of relative gene expression data using realtime quantitative PCR and the $2^{-\triangle \Delta \mathrm{CT}}$ method. Methods 25:402-408.

Mahoney, S. J., J. M. Dempsey, and J. Blenis. 2009. Cell signaling in protein synthesis ribosome biogenesis and translation initiation and elongation. Prog. Mol. Biol. Transl. Sci. 90:53-107.

Merrill, A. L., and B. K. Watt. 1973. Energy Value of Foods Basis and Derivation; Agricultural Handbook 74. U.S. Government Printing Office, Washington, DC.

Mitchell, H. H., and R. J. Block. 1946. Some relationships between the amino acid contents of proteins and their nutritive values for the rat. J. Biol. Chem. 163:599-620.

Moshel, Y., R. E. Rhoads, and I. Barash. 2006. Role of amino acids in translational mechanisms governing milk protein synthesis in murine and ruminant mammary epithelial cells. J. Cell. Biochem. 98:685-700.

Nadeau, E., J. E. Englund, and A. H. Gustafsson. 2007. Nitrogen efficiency of dairy cows as affected by diet and milk yield. Livest. Sci. 111:45-56.

NRC. 2001. Nutrient Requirements of Dairy Cattle. 7th ed. Natl. Acad. Press, Washington, DC. 
NRC. 2012. Nutrient Requirements of Swine. Natl. Acad. Press, Washington, DC.

Orellana, R. A., A. Jeyapalan, J. Escobar, J. W. Frank, H. V. Nguyen, A. Suryawan, and T. A. Davis. 2007. Amino acids augment muscle protein synthesis in neonatalpigs during acute endotoxemia by stimulating mTOR-dependent translation initiation. Am. J. Physiol. Endocrinol. Metab. 293:E1416-E1425.

Proud, C. G. 2004. mTOR-mediated regulation of translation factors by amino acids. Biochem. Biophys. Res. Commun. 313:429-436.

Redpath, N. T., E. J. Foulstone, and C. G. Proud. 1996. Regulation of translationelongation factor-2 by insulin via a rapamycin-sensitive signalling pathway. EMBO J. 15:2291-2297.

Ryazanov, A. G., E. A. Shestakova, and P. G. Natapov. 1988. Phosphorylation of elongation factor 2 by EF-2 kinase affects rate of translation. Nature 334:170-173.

Shah, O. J., J. C. Anthony, S. R. Kimball, and L. S. Jefferson. 2000 4E-BP1 and S6K1: Translational integration sites for nutritional and hormonal information in muscle. Am. J. Physiol. Endocrinol. Metab. 279:E715-E729.

Spears, R. A., R. A. Kohn, and A. J. Young. 2003. Whole-farm nitrogen balance on western dairy farms. J. Dairy Sci. 86:4178-4186.

Suryawan, A., A. S. Jeyapalan, R. A. Orellana, F. A. Wilson, H. V. Nguyen, and T. A. Davis. 2008. Leucine stimulates protein syn- thesis in skeletal muscle of neonatal pigs by enhancing mTORC1 activation. Am. J. Physiol. Endocrinol. Metab. 295:E868-E875.

von Liebig, J. 1863. The Natural Laws of Husbandry. D. Appleton and Co., New York, NY.

White, R. R., Y. Roman-Garcia, J. L. Firkins, M. H. VandeHaar, L. E. Armentano, T. McGill, R. Garnett, and M. D. Hanigan. 2016a. Evaluation of the 2001 Dairy NRC and derivation of new prediction equations. International Symposium on Energy and Protein Metabolism. Krakow, Poland. Wageningen Academic Publishers, the Netherlands.

White, R. R., S. Zhang, N. Regmi, and N. Trottier. 2016b. Quantifying variable amino acid efficiency in lactating sows. J. Dairy Sci. 99(Suppl. 1):17. (Abstr.)

Whitelaw, F. G., J. S. Milne, E. R. Orskov, and J. S. Smith. 1986. The nitrogen and energy metabolism of lactating cows given abomasal infusions of casein. Br. J. Nutr. 55:537-556.

Wu, M. M. 2014. The effects of amino acid nutritional deficiency on the expression of protein metabolism-related genes in the mammary gland and muscle tissues of lactating mice. Masters Thesis. Shandong Agriculture University, China. 